\title{
Shewanella chilikensis sp. nov., a moderately alkaliphilic gammaproteobacterium isolated from a lagoon
}

\section{Correspondence \\ Ch. Sasikala \\ r449@sify.com or \\ sasi449@yahoo.ie}

\author{
K. Sucharita, ${ }^{1}$ Ch. Sasikala, ${ }^{1}$ S. C. Park, ${ }^{2}$ K. S. Baik, ${ }^{2}$ C. N. Seong ${ }^{2}$ \\ and Ch. V. Ramana ${ }^{3}$
}
${ }^{1}$ Bacterial Discovery Laboratory, Centre for Environment, Institute of Science and Technology, J.N.T. University, Kukatpally, Hyderabad 500 085, India
${ }^{2}$ Department of Biology, College of Life Science and Natural Resources, Sunchon National University, Suncheon 540-742, Republic of Korea
${ }^{3}$ Department of Plant Sciences, School of Life Sciences, University of Hyderabad, PO Central University, Hyderabad 500 046, India

\begin{abstract}
A Gram-negative, motile, rod-shaped, facultatively anaerobic bacterium was isolated from sediment of Chilika Lagoon, a brackish water lagoon in India. The strain, designated $\mathrm{JC5}^{\top}$, was able to grow in the presence of $0-8.0 \% \mathrm{NaCl}$ and at $\mathrm{pH} 7.0-10.0$. The isolate was positive for oxidase and catalase and exhibited $\alpha$-haemolysis. The major fatty acids were iso- $\mathrm{C}_{15: 0}(18.3 \%)$, $\mathrm{C}_{16: 0}(11.3 \%), \mathrm{C}_{17: 1} \omega 8 \mathrm{c}(13.1 \%)$ and a summed feature, $\mathrm{C}_{16: 1} \omega 7 c$ and/or $\mathrm{C}_{16: 1} \omega 6 c$ (15.1\%). The genomic DNA G + C content was 54.6 mol\%. A phylogenetic tree based on the $16 \mathrm{~S}$ rRNA gene sequences showed that strain $\mathrm{JC}^{\top}$ forms a lineage within the genus Shewanella and is closely related to Shewanella haliotis DW01 ${ }^{\top}(98.0 \%)$, Shewanella algae ATCC $51192^{\top}$ (97.6\%) and Shewanella marina $\mathrm{C}^{\top}{ }^{\top}(95.8 \%)$. Further, genomic DNA-DNA hybridization of strain $\mathrm{JC}^{\top}$ with $S$. haliotis DW01 ${ }^{\top}$ and S. algae ATCC $51192^{\top}$ showed relatedness of only 42 and $23 \%$, respectively. On the basis of phenotypic and molecular genetic evidence, strain $\mathrm{JC5}^{\top}$ represents a novel species of the genus Shewanella, for which the name Shewanella chilikensis sp. nov. is proposed. The type strain is $\mathrm{JC5}^{\top}\left(=\mathrm{CCUG} 57101^{\top}=\mathrm{NBRC} 105217^{\top}=\mathrm{KCTC}\right.$ $22540^{\top}$ ).
\end{abstract}

The genus Shewanella is a member of the class Gammaproteobacteria (Anzai et al., 2000) and comprises a group of Gram-negative, motile, rod-shaped, oxidasepositive, non-fermentative and facultatively anaerobic aquatic and marine bacteria (Park et al., 2009; Gauthier et al., 1995; MacDonell \& Colwell, 1985; Venkateswaran et al., 1999). At the time of writing, the genus Shewanella comprised 48 recognized species (http://www.bacterio. cict.fr/s/shewanella.html). The majority of Shewanella species have been isolated from aquatic and marine environments and most can grow by anaerobic respiration (Bowman, 2005). While studying the anoxygenic phototrophic bacterial diversity of Chilika Lagoon, India, strain $\mathrm{JC}^{\mathrm{T}}$ appeared as a pale-brown colony on anaerobic agar slants used for purifying cultures of purple anoxygenic

The GenBank/EMBL/DDBJ accession number for the $16 \mathrm{~S}$ rRNA gene sequence of strain $\mathrm{JC5}^{\top}$ is $\mathrm{FM} 210033$.

Supplementary tables showing GN2 MicroPlate results for strain $\mathrm{JC5}^{\top}$ and cellular fatty acid compositions for strain $\mathrm{JC}^{\top}$ and its closest phylogenetic relatives are available with the online version of this paper. phototrophic bacteria. Strain $\mathrm{JC5}^{\mathrm{T}}$ did not contain any bacterial chlorophyll or carotenoids and analysis of its $16 \mathrm{~S}$ rRNA gene sequence indicated that the strain belongs to the genus Shewanella. In this communication, we propose a novel moderately alkaliphilic species of the genus Shewanella.

Strain $\mathrm{JC}^{\mathrm{T}}$ was isolated from a sediment sample taken from the southern part of Chilika Lagoon, near Barkul, Orissa, India $\left(19^{\circ} 47^{\prime} \mathrm{N} 85^{\circ} 49^{\prime} \mathrm{E}\right)$, on 12 May 2007. The sample that yielded strain $\mathrm{JC}^{\mathrm{T}}$ had a $\mathrm{pH}$ of 8.5 and salinity of $2 \%(\mathrm{w} / \mathrm{v})$. The sediment sample was originally used for the enrichment of purple bacteria in Pfennig's mineral medium (Biebl \& Pfennig, 1981) with $\left(1^{-1}\right) 3.0$ g sodium pyruvate as carbon source, $0.3 \mathrm{~g}$ yeast extract and $0.3 \mathrm{~g}$ Casamino acids as growth factors and $1.2 \mathrm{~g}$ ammonium chloride as nitrogen source. Phototrophic incubation $(2400$ lx) at $30{ }^{\circ} \mathrm{C}$ for $4-5$ days resulted in the formation of palecoloured enrichments, which were streaked directly onto agar slants $(25 \times 150 \mathrm{~mm}$ test tubes sealed with butyl rubber stoppers and the gas phase replaced with argon). Pale-brown colonies appeared after 2 days and the colonies 
were purified by repeated streaking on agar slants. The purified culture was grown in nutrient broth and designated strain $\mathrm{JC}^{\mathrm{T}}$. The pure culture of strain $\mathrm{JC}^{\mathrm{T}}$ was maintained under refrigeration at $4{ }^{\circ} \mathrm{C}$ and preserved as lyophilized cells.

Cells of strain $\mathrm{JC} 5^{\mathrm{T}}$ grown on nutrient agar were observed by phase-contrast microscopy (Olympus $\mathrm{BH}-2$ ) for shape, size and motility and by transmission electron microscopy (H-7500; Hitachi) for flagella. Utilization of organic compounds as carbon sources/electron donors was tested in Pfennig's medium (Biebl \& Pfennig, 1981) containing the specific organic compound $(0.35 \%, w / v)$ in the presence of yeast extract $(0.01 \%, \mathrm{w} / \mathrm{v})$. Fermentative growth was tested using triple-sugar iron medium and also with the methyl red-Voges-Proskauer method. Nitrogen source utilization was tested by replacing ammonium chloride with different nitrogen sources [sodium nitrate, sodium nitrite, urea and ammonium chloride (at $0.1 \%, \mathrm{w} / \mathrm{v}$ ) and $\mathrm{N}_{2}$ (gas phase replaced with nitrogen in tubes sealed with butyl rubber stoppers)]. Requirements for vitamins were tested by replacing yeast extract with different vitamins [vitamin $\mathrm{B}_{12}$, biotin, niacin, p-aminobenzoic acid, pantothenate, pyridoxal phosphate, riboflavin, thiamine or a cocktail of all these vitamins
$(0.02 \%, \mathrm{w} / \mathrm{v})]$ as growth factors. Biochemical tests (Table 1$)$ were carried out in prescribed media to meet the requirements of the standard methods as mentioned by Cappuccino \& Sherman (1998). Phylogenetically related strains (Shewanella haliotis DW01 ${ }^{\mathrm{T}}$, S. algae ATCC $51192^{\mathrm{T}}$ and $S$. marina $\mathrm{C} 4^{\mathrm{T}}$ ) were tested under the same conditions. Growth was measured turbidometrically at $540 \mathrm{~nm}$ from cultures after centrifugation at 15000 r.p.m. for $15 \mathrm{~min}$ and resuspension in distilled water. Other biochemical tests were performed using GN2 MicroPlates (Biolog) (Supplementary Table S1, available in IJSEM Online) according to the manufacturer's instructions except that strains were suspended in distilled water supplemented with $2 \%(\mathrm{w} / \mathrm{v})$ sea salts. Antibiotic resistance was determined using the disc diffusion method with commercial antibiotic-impregnated discs (BBL Becton Dickinson). The results were interpreted according to the guidelines set down by Clinical Laboratory Standards Institute (CLSI, 2003). Haemolytic activity was tested on trypticase soy agar supplemented with $5 \%(\mathrm{v} / \mathrm{v})$ defibrinated sheep blood (Benson, 2002).

Fatty acid methyl esters were prepared from cells grown in the above medium and identified according to the instructions of the Microbial Identification System

Table 1. Phenotypic characteristics that differentiate strain $\mathrm{JC}^{\top}$ from its closest phylogenetic neighbours

Strains: 1, Shewanella chilikensis sp. nov. JC5 ${ }^{\mathrm{T}} ; 2$, S. algae ATCC $51192^{\mathrm{T}}$ (data from this study unless indicated); 3, S. haliotis DW01 ${ }^{\mathrm{T}}(\mathrm{Kim}$ et al., 2007); 4, S. marina $\mathrm{C}^{\mathrm{T}}$ (Park et al., 2009). All strains are motile by single polar flagellum, tolerant of $6 \% \mathrm{NaCl}$, positive for catalase, oxidase and $\mathrm{H}_{2} \mathrm{~S}$ production and negative for starch hydrolysis, glucose fermentation, citrate and fructose utilization and indole production. + , Positive; W, weakly positive; -, negative, R, resistant; s, sensitive.

\begin{tabular}{|c|c|c|c|c|}
\hline Characteristic & 1 & 2 & 3 & 4 \\
\hline Colony colour & Pale brown & Pink & Pink-orange & Pale brown \\
\hline $4{ }^{\circ} \mathrm{C}$ & - & - & - & + \\
\hline $42{ }^{\circ} \mathrm{C}$ & + & + & + & - \\
\hline $\mathrm{pH}$ range (optimum) & $7-10(8)$ & $5-11(7-8)$ & $5-11(7)$ & $5-10(7)$ \\
\hline Malate & + & - & + & - \\
\hline Mannose & - & + & - & - \\
\hline Glucose & - & + & - & $\mathrm{W}$ \\
\hline Casein hydrolysis & + & + & - & + \\
\hline Gelatin liquefaction & - & + & + & + \\
\hline Nitrate reduction & - & + & + & + \\
\hline Haemolysis & $+(\alpha)$ & + & - & + \\
\hline \multicolumn{5}{|l|}{ Antibiotic sensitivity } \\
\hline Penicillin & s & $\mathrm{R}$ & $\mathrm{R}$ & $\mathrm{R}$ \\
\hline Vancomycin & s & $\mathrm{R}$ & $\mathrm{R}$ & $\mathrm{R}$ \\
\hline DNA G $+\mathrm{C}$ content $(\mathrm{mol} \%)$ & 54.6 & $52-54^{b}$ & 53.7 & 40.8 \\
\hline
\end{tabular}

${ }^{\star}$ Data taken from: $a$, Simidu et al. (1990); $b$, Nozue et al. (1992) (range of values for 36 strains, including the type strain). 
(Sasser, 1990). The DNA G + C content was determined by HPLC using the methods of Mesbah et al. (1989). The taxonomic relationships between strain $\mathrm{JC}^{\mathrm{T}}$ and S. algae ATCC $51192^{\mathrm{T}}$ and $S$. haliotis $\mathrm{DW} 01^{\mathrm{T}}$ were examined further using DNA-DNA hybridization. Genomic relatedness was determined using a membrane filter technique (Seldin \& Dubnau, 1985) using a DIG High Prime DNA Labelling and Detection starter kit II (Roche).

Genomic DNA was obtained from 1-2 ml well-grown culture from nutrient broth (dehydrated medium; HiMedia) using a genomic DNA extraction kit (Qiagen). PCR amplification was performed as described by Imhoff et al. (1998) with recombinant Taq polymerase and the primers $\mathrm{F}^{\prime}-27$ (5'-GTTTGATCCTGGCTCAG-3') and R'1489 (5'-TACCTTGTTACGACTTCA-3') (positions 11-27 and 1489-1506, respectively, according to the Escherichia coli 16S rRNA gene sequence numbering system of the International Union of Biochemistry). Sequencing of the amplification products was outsourced to MWG Biotech Pvt Ltd (Bangalore, India). The resultant sequence of strain $\mathrm{JC5}^{\mathrm{T}}$ was aligned manually against sequences obtained from the GenBank database. Phylogenetic trees were inferred from bases that were available for all sequences (positions 42-1450; E. coli numbering system) using neighbour-joining (Saitou \& Nei, 1987), FitchMargoliash (Fitch \& Margoliash, 1967) and maximumlikelihood (Guindon \& Gascuel, 2003) methods. Evolutionary distance matrices were generated according to Jukes \& Cantor (1969). The resultant neighbour-joining tree topology was evaluated by bootstrap analyses (Felsenstein, 1985) based on 1000 resamplings. Alignment and phylogenetic analyses were carried out using the jPHYDIT program (available at http://plaza.snu.ac.kr/ jchun/jphydit/) and PAUP 4.0 (Swofford, 1998) as described by Chun et al. (2000).

On nutrient agar, aerobically grown colonies of strain $\mathrm{JC}^{\mathrm{T}}$ are pale brown, circular and convex with entire margins. Individual cells are rods, $1.5-2.0 \mu \mathrm{m}$ long and $0.5-1.0 \mu \mathrm{m}$ wide. Electron microscopy showed that the strain has a single polar flagellum. Substrates that were utilized as carbon sources/electron donors under organoheterotrophic conditions are given in Table 1. Ammonium chloride, nitrate and glutamate were used as nitrogen sources for growth, while nitrite and molecular nitrogen were not utilized. Addition of $\mathrm{NaCl}$ to the medium was not required for growth of strain $\mathrm{JC}^{\mathrm{T}}$, but the strain could tolerate $\mathrm{NaCl}$ up to a concentration of $8.0 \%$. Strain $\mathrm{JC}^{\mathrm{T}}$ could grow at pH 7.0-10.0 (optimum pH 8.0) (Fig. 1) and at 25$42{ }^{\circ} \mathrm{C}$ (optimum $28-30{ }^{\circ} \mathrm{C}$ ). There is no vitamin requirement for strain $\mathrm{JC}^{\mathrm{T}}$; however, addition of yeast extract $(0.01 \%, w / v)$ enhanced growth. Strain $\mathrm{JC}^{\mathrm{T}}$ was catalasepositive and $\alpha$-haemolytic. Starch was not hydrolysed; casein was hydrolysed. Gelatin was not liquefied and indole was not produced from L-tryptophan. Although lipase and acid phosphatase tests were negative, strain $\mathrm{JC}^{\mathrm{T}}$ showed urease activity. Acid formation from glucose and lactose

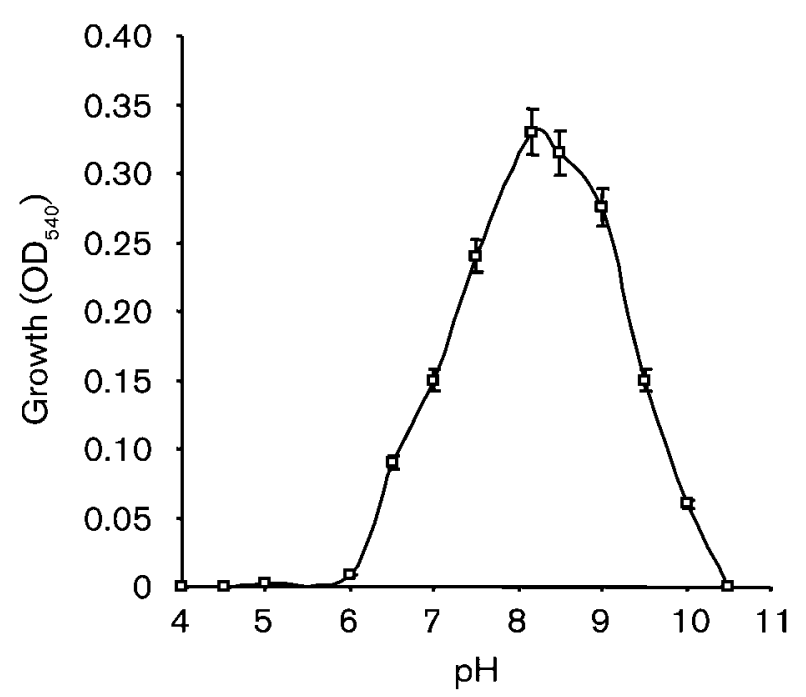

Fig. 1. Effect of $\mathrm{pH}$ on the growth of strain $\mathrm{JC} 5^{\top}$. Values are means $\pm S D$ from 2 determinations.

was negative. These results show clear phenotypic differences from recognized Shewanella species (Table 1).

The whole-cell fatty acid profile of strain $\mathrm{JC}^{\mathrm{T}}$ (Supplementary Table S2) included $\mathrm{C}_{12: 0}(3.5 \%), \mathrm{C}_{16: 0}$ $(11.3 \%)$, iso- $\mathrm{C}_{13: 0}(4.3 \%)$, iso- $\mathrm{C}_{15: 0}(18.3 \%), \mathrm{C}_{17: 1} \omega 8 c$ $(13.1 \%)$ and summed feature $4 \quad\left(\mathrm{C}_{16: 1} \omega 7 c\right.$ and/or $\left.\mathrm{C}_{16: 1} \omega 6 c ; 15.1 \%\right)$. Significant differences in the contents of predominant fatty acids between strain $\mathrm{JC}^{\mathrm{T}}$ and type strains of related species were found: e.g. summed feature 4 was found only in strain $\mathrm{JC}^{\mathrm{T}}$ and summed feature 3 was found only in the type strains of other Shewanella species (although both summed features include $\mathrm{C}_{16: 1} \omega 7 c$ ). The DNA G + C content of strain JC5 ${ }^{\mathrm{T}}$ was $54.6 \mathrm{~mol} \%$ (HPLC), which is similar to values reported for $S$. algae and $S$. haliotis.

Preliminary sequence comparison with $16 \mathrm{~S}$ rRNA gene sequences held in GenBank indicated that our isolate was related closely to the genus Shewanella. After manual alignment of the newly determined sequence (1442 nt) with those of representatives of the genus Shewanella, strain $\mathrm{JC5}^{\mathrm{T}}$ showed highest $16 \mathrm{~S}$ rRNA gene sequence similarity to sequences from S. haliotis $\mathrm{DW}^{\mathrm{T}}{ }^{\mathrm{T}}(98.0 \%)$ and S. algae ATCC $51192^{\mathrm{T}}(97.6 \%)$. To elucidate the phylogenetic relationship between the isolate and other species of the genus Shewanella, phylogenetic trees were constructed using three different tree-making algorithms. The neighbour-joining tree (Fig. 2) showed that strain JC5 ${ }^{\mathrm{T}}$ formed a distinct branch with the clade comprising $S$. haliotis $\mathrm{DW} 01^{\mathrm{T}}$ and S. algae ATCC $51192^{\mathrm{T}}$, and this was also observed in the Fitch-Margoliash tree (not shown).

Genomic DNA-DNA hybridization of strain $\mathrm{JC}^{\mathrm{T}}$ with $S$. haliotis $\mathrm{DW}^{\mathrm{T}}$ and S. algae ATCC $51192^{\mathrm{T}}$ showed relatedness values of only 42 and $23 \%$, respectively. Thus, levels of genetic relatedness according to 


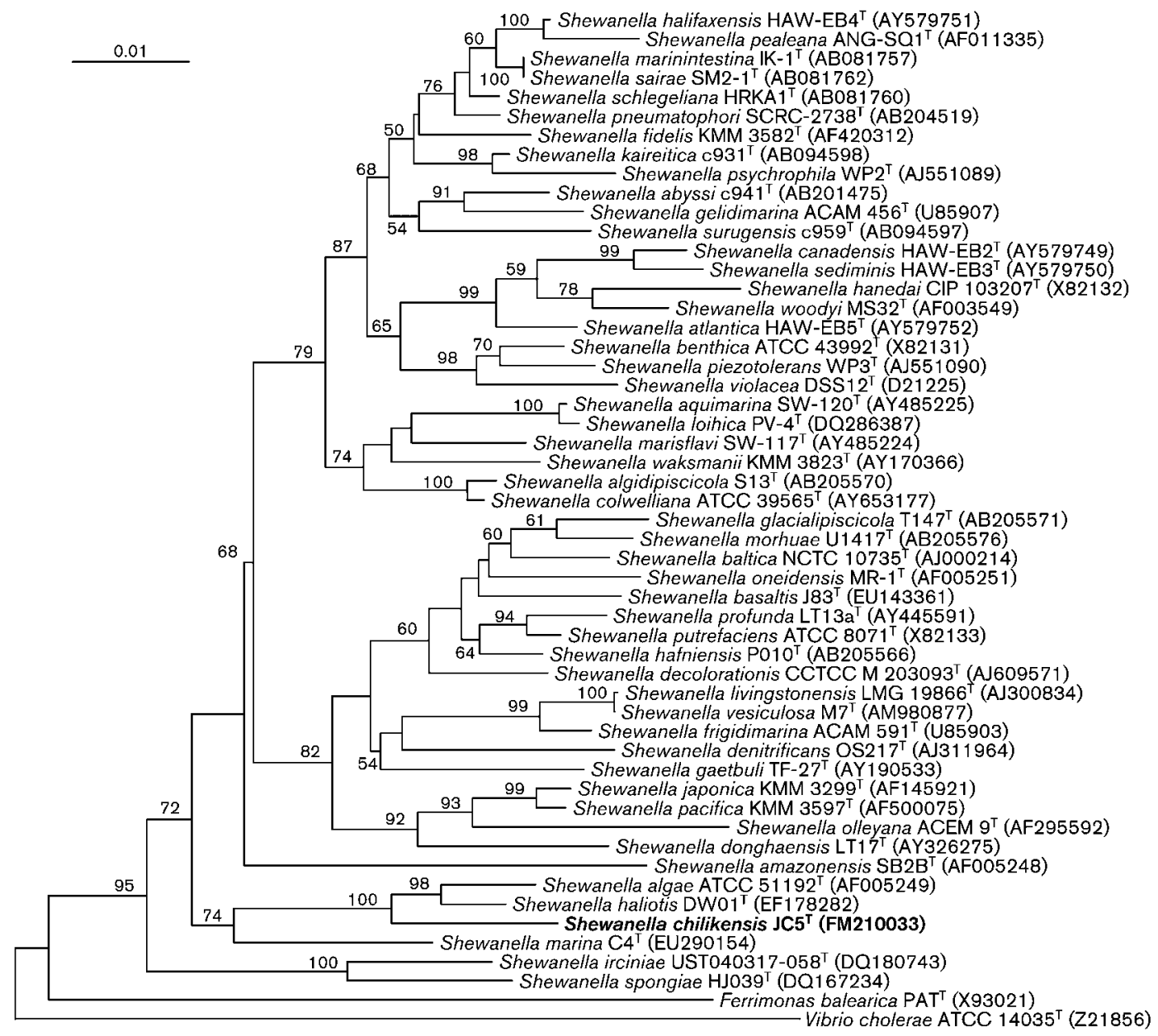

Fig. 2. Neighbour-joining tree based on nearly complete 16S rRNA gene sequences showing relationships between strain $\mathrm{JC5}^{\top}$ and members of the genus Shewanella. Percentages at nodes are levels of bootstrap support based on 1000 resampled datasets. The sequence of Vibrio cholerae ATCC $14035^{\top}$ was used as an outgroup. Bar, 0.01 nucleotide substitutions per position.

DNA-DNA hybridization experiments were less than $70 \%$, which supports the conclusion that strain $\mathrm{JC}^{\mathrm{T}}$ represents a novel and distinct species.

On the basis of the phylogenetic, genomic and phenotypic data, it is clear that strain $\mathrm{JC}^{\mathrm{T}}$ represents a novel species within the genus Shewanella (Bowman, 2005), for which the name Shewanella chilikensis sp. nov. is proposed.

\section{Description of Shewanella chilikensis sp. nov.}

Shewanella chilikensis (chi.li.ken'sis. N.L. fem. adj. chilikensis pertaining to Chilika, referring to the isolation of the type strain from Chilika lagoon, Orissa, India).

On nutrient agar, aerobically grown colonies are pale brown, circular and convex with entire margins. Cells are rod-shaped, $1.5-2.0 \mu \mathrm{m}$ long and $0.5-1.0 \mu \mathrm{m}$ wide and motile by single polar flagellum. Gram-negative, non-fermentative, non-spore-forming and facultatively anaerobic. Moderately alkaliphilic (range pH 7.0-10.0, optimum $\mathrm{pH} 8.0$ ). Growth occurs with $0-8 \%$ (w/v) $\mathrm{NaCl}$ and at $25-42{ }^{\circ} \mathrm{C}$ (optimum $28-30{ }^{\circ} \mathrm{C}$ ). No vitamin requirement but yeast extract enhances growth. Oxidaseand catalase-positive. Negative for nitrate reduction and glucose fermentation. Produces urease and ornithine decarboxylase, but not lipase, arginine dihydrolase or lysine decarboxylase. Produces $\mathrm{H}_{2} \mathrm{~S}$ but not indole. Hydrolyses casein but not gelatin or starch. Acid production from carbohydrates (glucose, lactose) and acid phosphatase activity are negative. The carbon sources that are utilized include fumarate, malate, pyruvate, succinate, glycogen, Tweens 40 and $80, \mathrm{~N}$-acetylgalactosamine, $\mathrm{N}$ acetylglucosamine, pyruvic acid methyl ester, acetic acid, cis-aconitic acid, citric acid, formic acid, $\alpha$ - and $\beta$ hydroxybutyric acid, $\alpha$-ketobutyric acid, $\alpha$-ketoglutaric acid, $\alpha$-ketovaleric acid, DL-lactic acid, propionic acid, succinic acid, bromosuccinic acid, L-alanine, L-alanyl glycine, L-glutamic acid, glycyl L-aspartic acid, glycyl 
L-glutamic acid, L-leucine, L-proline, L-serine, L-threonine, inosine, uridine and thymidine. Citrate is not utilized. Exhibits $\alpha$-haemolysis. The predominant fatty acids $(>5 \%)$ are iso- $\mathrm{C}_{15: 0}, \mathrm{C}_{16: 0}, \mathrm{C}_{17: 1} \omega 8 c$ and summed feature $4\left(\mathrm{C}_{16: 1} \omega 7 c\right.$ and/or $\left.\mathrm{C}_{16: 1} \omega 6 c\right)$. The DNA G $+\mathrm{C}$ content of the type strain is $54.6 \mathrm{~mol} \%$ (HPLC).

The type strain, $\mathrm{JC5}^{\mathrm{T}}\left(=\mathrm{CCUG} 57101^{\mathrm{T}}=\mathrm{NBRC} 105217^{\mathrm{T}}\right.$ $=$ KCTC $22540^{\mathrm{T}}$ ), was isolated from sediment of Chilika Lagoon, Orissa, India.

\section{Acknowledgements}

We thank Dr J. Euzéby for his expert suggestion on the correct species epithet and Latin etymology. Funding received for this work from MoES is acknowledged. Facilities used under the DST, FIST-II are acknowledged from University of Hyderabad.

\section{References}

Anzai, Y., Kim, H., Park, J. Y., Wakabayashi, H. \& Oyaizu, H. (2000). Phylogenetic affiliation of the pseudomonads based on 16S rRNA sequence. Int J Syst Evol Microbiol 50, 1563-1589.

Benson, H. J. (2002). Microbiological Applications: A Laboratory Manual in General Microbiology, 8th edn. New York: McGraw-Hill.

Biebl, H. \& Pfennig, N. (1981). Isolation of members of the family Rhodospirillaceae. In The Prokaryotes, vol. 1, pp. 267-273. Edited by M. P. Starr, H. Stolp, H. G. Trüper, A. Balows \& H. G. Schlegel. Berlin: Springer.

Bowman, J. P. (2005). Genus XIII. Shewanella. In Bergey's Manual of Systematic Bacteriology, 2nd edn, vol. 2, part B, pp. 480-491. Edited by D. J. Brenner, N. R. Krieg, J. T. Staley \& G. M. Garrity. New York: Springer.

Cappuccino, J. G. \& Sherman, N. (1999). Microbiology: a Laboratory Manual, 5th edn. Menlo Park, CA: Benjamin/Cummings.

Chun, J., Bae, K. S., Moon, E. Y., Jung, S. O., Lee, H. K. \& Kim, S. J. (2000). Nocardiopsis kunsanensis sp. nov., a moderately halophilic actinomycete isolated from a saltern. Int J Syst Evol Microbiol 50, 1909-1913.

CLSI (2003). Performance standards for antimicrobial disk susceptibility tests, 8th edn. Approved Standard M2-A8. Wayne, PA: Clinical Laboratory Standards Institute.

Felsenstein, J. (1985). Confidence limits on phylogenies: an approach using the bootstrap. Evolution 39, 783-791.

Fitch, W. M. \& Margoliash, E. (1967). Construction of phylogenetic trees. Science 155, 279-284.

Gauthier, G., Gauthier, M. \& Christen, R. (1995). Phylogenetic analysis of the genera Alteromonas, Shewanella, and Moritella using genes coding for small-subunit rRNA sequences and division of the genus Alteromonas into two genera, Alteromonas (emended) and Pseudoalteromonas gen. nov., and proposal of twelve new species combinations. Int J Syst Bacteriol 45, 755-761.

Guindon, S. \& Gascuel, O. (2003). A simple fast and accurate algorithm to estimate large phylogenies by maximum likelihood. Syst Biol 52, 696-704.

Imhoff, J. F., Süling, J. \& Petri, R. (1998). Phylogenetic relationships among the Chromatiaceae, their taxonomic reclassification and description of the new genera Allochromatium, Halochromatium, Isochromatium, Marichromatium, Thiococcus, Thiohalocapsa and Thermochromatium. Int J Syst Bacteriol 48, 1129-1143.

Jukes, T. H. \& Cantor, C. R. (1969). Evolution of protein molecules. In Mammalian Protein Metabolism, vol. 3, pp. 21-132. Edited by H. N. Munro. New York: Academic Press.

Kim, D., Baik, K. S., Kim, M. S., Jung, B. M., Shin, T. S., Chung, G. H., Rhee, M. S. \& Seong, C. N. (2007). Shewanella haliotis sp. nov., isolated from the gut microflora of abalone, Haliotis discus hannai. Int J Syst Evol Microbiol 57, 2926-2931.

MacDonell, M. T. \& Colwell, R. R. (1985). Phylogeny of the Vibrionaceae, and recommendation for two new genera, Listonella and Shewanella. Syst Appl Microbiol 6, 171-182.

Mesbah, M., Premachandran, U. \& Whitman, W. B. (1989). Precise measurement of the $\mathrm{G}+\mathrm{C}$ content of deoxyribonucleic acid by highperformance liquid chromatography. Int J Syst Bacteriol 39, 159-167.

Nozue, H., Hayashi, T., Hashimoto, Y., Ezaki, T., Hamasaki, K., Ohwada, K. \& Terawaki, Y. (1992). Isolation and characterization of Shewanella alga from human clinical specimens and emendation of the description of S. alga Simidu et al., 1990, 335. Int J Syst Bacteriol 42, 628-634.

Park, S. C., Baik, K. S., Kim, M. S., Kim, D. \& Seong, C. N. (2009). Shewanella marina sp. nov., isolated from seawater. Int J Syst Evol Microbiol 59, 1888-1894.

Saitou, N. \& Nei, M. (1987). The neighbor-joining method: a new method for reconstructing phylogenetic trees. Mol Biol Evol 4, 406425.

Sasser, M. (1990). Identification of bacteria by gas chromatography of cellular fatty acids, MIDI Technical Note 101. Newark, DE: MIDI Inc.

Seldin, L. \& Dubnau, D. (1985). Deoxyribonucleic acid homology among Bacillus polymyxa, Bacillus macerans, Bacillus azotofixans, and other nitrogen-fixing Bacillus strains. Int J Syst Bacteriol 35, 151-154.

Simidu, U., Kita-Tsukamoto, K., Yasumoto, T. \& Yotsu, M. (1990). Taxonomy of four marine bacterial strains that produce tetrodotoxin. Int J Syst Bacteriol 40, 331-336.

Swofford, D. L. (1998). Phylogenetic Analysis Using Parsimony (PAUP). Version 4. Sunderland, MA: Sinauer Associates.

Venkateswaran, K., Moser, D. P., Dollhopf, M. E., Lies, D. P., Saffarini, D. A., MacGregor, B. J., Ringelberg, D. B., White, D. C., Nishijima, M. \& other authors (1999). Polyphasic taxonomy of the genus Shewanella and description of Shewanella oneidensis sp. nov. Int J Syst Bacteriol 49, 705-724. 